A Case for Variable Rate Mortgages (p. 1)

Last Fall's Policy Changes:

A Sound Program for Reducing Inflation (p. 5)

District Conditions (p. 11)

1977-78 Contents (p. 13)
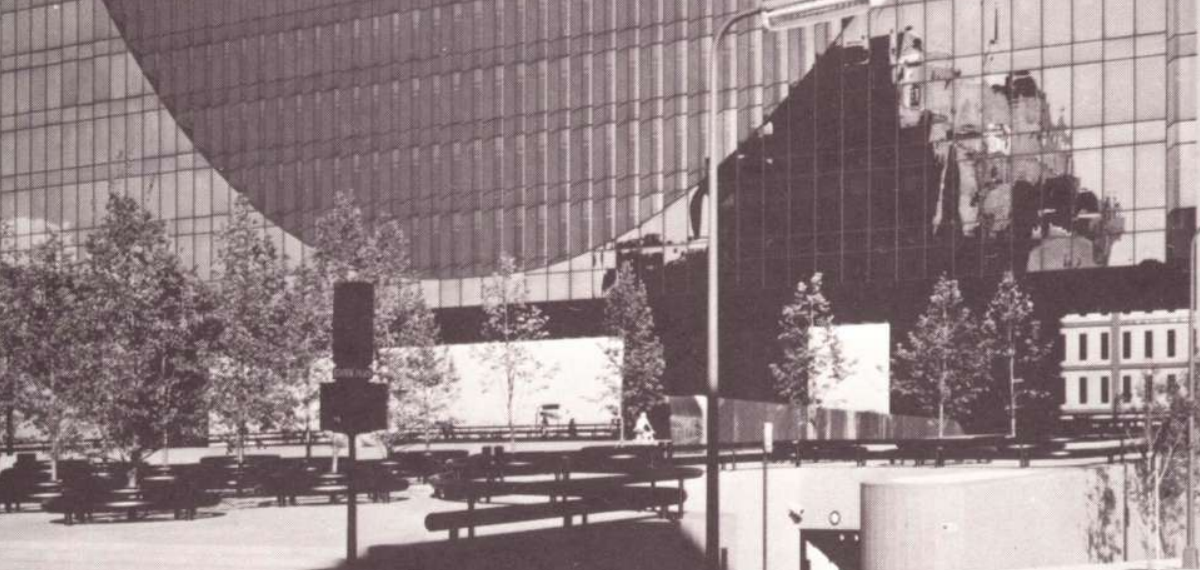


\section{Federal Reserve Bank of Minneapolis Quarterly Review vol. 3, №.1}

This publication primarily presents economic research aimed at improving policy making by the Federal Reserve System and other governmental authorities.

Produced in the Research Department. Edited by Arthur J. Rolnick, Senior Economist, Kathleen S. Rolfe, Editor/Writer and Visuals Specialist, and Alan Struthers, Jr., Editor/Writer. Graphic design by Phil Swenson, Graphic Services Department.

Address requests for additional copies to the Research Department, Federal Reserve Bank, Minneapolis, Minnesota 55480.

Articles may be reprinted if the source is credited and the Research Department is provided with copies of reprints.

The views expressed herein are those of the authors and not necessarily those of the Federal Reserve Bank of Minneapolis or the Federal Reserve System. 


\title{
Last Fall's Policy Changes: A Sound Program for Reducing Inflation
}

\author{
Thomas M. Supel \\ Senior Economist \\ Research Department \\ Federal Reserve Bank of Minneapolis
}

For much of 1978, Congress and the Administration were caught in a dilemma. They wanted to reduce inflation but feared that any anti-inflation move could easily cause a recession and thereby push unemployment to high levels. President Carter's decision in the fall of 1978 to inaugurate a new program to fight inflation and stop the decline of the dollar was therefore extremely difficult. The first part of the program, consisting mainly of guidelines for wages and prices, has done little to change the outlook for inflation. However, the second part of the programwith its efforts to slow the growth of money, cut the costs of government regulation, and support the dollar in foreign exchange-is a necessary step toward a stronger dollar and more moderate inflation, and it has not seriously increased the chances of a recession.

This is not to say there is no chance of a recession. For example, if the political turmoil in Iran were to cause a major disruption in oil supplies, it could precipitate a more serious slowdown than we are projecting. And similar kinds of economic shocks could do the same. The program itself, however, is a sound way to fight inflation and promote economic stability in the long run, and it is not likely to cause the recession so many predict.

\section{Before the Fall}

\section{Inflation became the nation's most serious economic problem}

Before the fall policy changes, most of the people in a position to make decisions for the government were concerned primarily with output, not inflation. Perhaps they were particularly sensitive about output because the gross national product (GNP), adjusted for inflation, actually declined in the first quarter of 1978, raising fears of a recession.

The growth in real output, though, was not a serious problem. It recovered in the second quarter and continued at near its trend rate during the third quarter, according to the data available in October. Based on what was known then, it was more reasonable to predict that real output would continue to grow steadily than that it would decline. In the third quarter, real final sales rose at a 4 percent rate, only slightly below the rate experienced during recent strong growth years. New orders for equipment and new contracts for business structures advanced strongly, suggesting that business investment would continue to grow. Construction of new homes continued at an unexpectedly strong pace, despite high mortgage rates. The composite index of leading indicators continued to advance. Finally, there were no serious overall weaknesses or sectoral imbalances in the economy which could have prevented continued expansion. The main cause for concern was the falling exchange rate of the dollar. If the dollar's problems got no worse, however, the real economy looked like it would grow 3.5 to 4 percent in 1979, and there seemed to be little danger of a recession.

Some effort to control inflation, though, was becoming increasingly necessary. The rate of inflation, which averaged less than 7 percent during 1977, jumped to nearly 10 percent during the first half of 1978. Meanwhile, public opinion polls began to show that inflation was bothering people more than any other economic problem in the country. In October, before the President's policy announcements, inflation looked like it was going to be worse in 1979 than in 1978 . 
It looked like it would be getting worse principally because of accommodating economic policies. The projected budget deficit for the 1978 fiscal year, for instance, was going to be extremely large $-\$ 50$ billion. The growth in the money supply, which had been quite rapid, showed no signs of slowing. And the new social security and minimum wage laws were certain to push up the cost of labor.

Such policies produced continued deterioration of the value of the dollar in foreign exchange, a deterioration that sometimes made the dollar's loss of purchasing power at home look mild in comparison. Against the Japanese yen, the dollar dived 27 percent during the first ten months of 1978. Relative to a basket of foreign currencies, it declined 8.6 percent.

This drop in the dollar might appear to matter only to tourists and multinational corporations, but it comes back to haunt the domestic economy. It makes domestic goods cheaper abroad, thus increasing the demand for them and raising their prices. In addition, it makes imported goods like cars and televisions more expensive and tempts domestic manufacturers to raise the prices of goods that compete with imports. By these means, the drop in the dollar gets translated into greater domestic inflation. And that's not the end of the trouble. As the dollar's international losses add to domestic inflation, people see that the dollar is not holding its purchasing power. They try to sell their dollars, and once again the exchange value of the dollar drops, starting the cycle all over again.

But even if the international pressures on inflation had disappeared, the domestic pressures from monetary and fiscal policy and new wage-related legislation would have been enough to keep inflation accelerating. In October 1978, because of these domestic pressures, inflation seemed destined to rise to 8 or 9 percent in 1979, even if the international problems were solved.

\section{The government acted cautiously}

For much of 1978, although output was normal and inflation was rising, the government moved cautiously on inflation. In the spring, the Administration tried to postpone and reduce the tax cut it had proposed earlier. It also revised the projected federal deficit in late summer. It cut the January projections for the deficits for each of the next two fiscal years by $\$ 10$ billion to $\$ 20$ billion. These reductions came about largely because federal outlays were less and tax revenues greater than originally foreseen, not because the Administration had planned a major change of policy. But fiscal policy was beginning to acknowledge the inflation problem.

Monetary policy, however, was not. Back in 1977, M1, the sum of currency and private checking accounts, had grown at about an 8 percent rate. In 1978, when the rate of inflation was accelerating, the growth of the money supply continued at about an 8 percent annual rate, much faster than the target announced by the Federal Reserve.

\section{Some forecasters expected a recession}

The government's initial caution on inflation received the support of the many forecasters who expected a recession. One of their reasons for expecting a recession was that the current recovery was older than average and thus had a good chance of dying. This was not a convincing argument, however. The recovery was indeed older than the average, but there are no natural laws that prevent a recovery from continuing long past the average.

Another of their reasons for expecting a recession was that businesses would unintentionally cause one. Businesses, these forecasters predicted, would accumulate excessive inventories by the end of 1978 and would consequently have to reduce production during 1979. This argument was not convincing either. Although inventories vary over the course of the business cycle, businesses have not regularly accumulated large inventories before a recession. To do this in such a predictable way would be to make costly and avoidable mistakes. Companies that do this would lose profits and risk being driven out of business by shrewder competitors. Businesses have doubtlessly made errors, some of which may have led to a recession. But they have not made systematic or predictable ones-the kind that foreshadow recessions or other economic events. And the data show this. In recent history, businesses have tended to reduce their inventories after a recession was in progress, not before it began. Clearly, these inventory reductions were a reaction to the recession, not a cause of it.

Some of the forecasters who predicted a recession also thought that consumers would unintentionally cause one. They believed that consumers, who had been buying goods in anticipation of further 
inflation, would soon be unable to keep spending or borrowing as much, which would lead to a recession. The evidence, however, did not necessarily suggest that consumers were buying goods in anticipation of inflation. The greater consumer debt could have been explained simply by the increase in the number of people aged 25 to 35 who usually carry larger debts. Moreover, even if consumers had been buying goods in anticipation of inflation, they wouldn't have to stop as long as inflation continued to push up incomes along with prices.

In the fall of 1978, in sum, all the evidence suggested that businesses would keep producing, consumers would keep spending, and the economy would keep growing strongly throughout 1979 .

\section{The Fall Anti-Inflation Program}

\section{A Disappointing Guidelines Program}

As it became clear that inflation was the nation's biggest economic problem, President Carter began to take more decisive steps. He made public the first part of his anti-inflation plan, the guidelines program, on October 24. This program had three main points:

- Wage and price guidelines. Total labor compensation, including fringe benefits, was restricted to an increase of no more than 7 percent. The total price increase was limited to $1 / 2$ percentage point below the 1976-77 average increase or to about 5.7 percent. As an alternative, businesses could keep the same profit margin that they had had in those years. Compliance was supposedly voluntary, but firms that didn't comply could lose important government contracts.

- Real wage insurance for workers who accept contracts within these guidelines. Subject to the approval of Congress, such workers would receive a tax credit to make up for their losses in purchasing power if the actual inflation rate exceeded 7 percent.

- A reduction in the federal deficit for fiscal year 1980 to $\$ 30$ billion or less.

These points are still part of the Administration's antiinflation program, although some have since been modified. At the time they were announced, President Carter apparently had no plans to expand the anti-inflation program. He presented these elements as if they were complete and sufficient.

This program was an attack on the wrong front. The guidelines, for instance, could not be very effective. In the United States, wage and price restrictions have worked temporarily if at all. They have managed to hold prices down for a short while, but the longer they were in force, the more serious problems they caused-and as soon as they were removed, prices moved quickly back to where they would have been. ${ }^{1}$ Wage and price guidelines have always failed because they have no bearing on the actual causes of inflation and therefore have little impact on inflation one way or the other.

The proposal to establish real wage insurance promised to be even less effective. Although its purpose was to protect labor in the event that the other parts of the program did not succeed, it could be disastrously inflationary. The Administration apparently believed that keeping wages down had a good chance of keeping inflation down, so that wage insurance would be an inexpensive gesture. But suppose this didn't work. What if labor cooperated and there was a drought, an oil embargo, or a war somewhere that disrupted our economy? Such events-by no means unlikely - could cause more inflation than the Administration hoped for, forcing the government to shell out billions of dollars at a time when it should be reducing expenditures. If the wage insurance plan had economy-wide coverage, it could cost the government up to $\$ 11$ billion for each percentage point the inflation rate exceeded 7 percent. Under the wage insurance scheme, more inflation would quickly create large deficits. But these large deficits, in turn, would create more inflation. Then the government would have to pay out more and more insurance money, and the destructive process would continue. Noting this possibility, the Administration put limits on how much it would pay out.

The Administration's pledge to hold the 1980 deficit to $\$ 30$ billion was the one substantive announcement of October 24 . Unfortunately, the credibility of this announcement was undercut by the

'For further discussion of the problems with wage and price controls, see Charles H. Whiteman, "A New Investigation of the Impact of Wage and Price Controls," Federal Reserve Bank of Minneapolis Quarterly Review, Spring 1978, pp. 2-8. 
weakness of the other parts of the program.

As a whole, the guidelines program did not attack the causes of inflation. The heavy reliance on wage and price guidelines and real wage insurance-rather than the government deficit-suggested that the private sector-not Washington, D.C. - was to blame for inflation. While the deficit is not the only cause of inflation, it is the major factor that the Administration and Congress have reasonable and legitimate control over, and it is a key means by which government policies are translated into future inflation.

The judgment of the marketplace was that this program was weak. On the day after the President's announcement, both short- and long-term interest rates rose, indicating that people expected a higher GNP. A higher GNP could be the result of either more inflation or more production. But if people expected more production, the stock market should have done well; instead, it fell. The most consistent explanation for this was that people expected higher inflation. In other words, interest rates were up because the inflation premium - the amount borrowers were willing to pay to compensate lenders for the effects of inflation - was up. To complete the picture, the foreign exchange value of the dollar fell dramatically, because fewer people in international markets wanted to hold dollars if inflation in the United States was going to get worse. The policy initiatives of October 24 clearly did not improve the market's outlook for inflation in 1979.

\section{A Gratifying Dollar Defense Program}

The market's distaste for the guidelines program was not lost on the Administration. Seeing that a new direction for policy was necessary, President Carter announced the second part of his anti-inflation program on November 1. This part of the program, which is sometimes called the dollar defense program, also had three main points:

- Slower money growth. This was to be accomplished by increasing the discount rate (the interest rate banks pay to the Federal Reserve for short-term loans), the federal funds rate (the interest rate banks pay each other for short-term loans), and the reserve requirements (the funds member banks must keep at the Federal Reserve) on large time deposits.

\section{- An attempt to cut the costs of government regula-} tion.

- A program to intervene in foreign exchange markets, raising $\$ 30$ billion to maintain the value of the dollar.

These measures were a major offensive against inflation. The increase in the discount rate, the federal funds rate, and the reserve requirements promised to stem the growth of the money supply and reduce the demand for goods and services both domestically and internationally, thus lowering inflation. The attempt to cut the costs of government regulation would lower inflation by removing some unnecessary expenses for both government and private industry. The plan to rescue the dollar would also lower inflation by slowing down the vicious inflationary spiral started by the dollar's falling exchange rate. If the dollar became stable, at least some of the pressures that produced accelerating inflation would be eliminated. ${ }^{2}$

Assuming that the attempts to control wages and prices that were announced earlier would not have any adverse affects, it was reasonable to predict after the President's second announcement that the slower money growth, the more efficient regulation, and the more stable dollar would succeed in lowering inflation. In the context of these measures, the budget proposal from the President's first announcementthe $\$ 30$ billion projected deficit for fiscal 1980looked more believable. Reducing the deficit would certainly reduce inflationary pressures, especially in combination with the other measures.

${ }^{2}$ In "International Monetary Reform: The Feasible Alternatives" (Federal Reserve Bank of Minneapolis Quarterly Review, Summer 1978, pp. 2-7), John Kareken and Neil Wallace demonstrate that floating exchange rates do not provide a stable international monetary system unless each country restricts the movement of capital to other countries. While the U.S. has had floating rates, it has not had capital controls. It has thus had to deal with an unstable exchange rate.

The only other stable system, Kareken and Wallace explain, is for countries to agree on fixed exchange rates and coordinated budget policies. The anti-inflation program is a step in the direction of this alternative system. The recent moves to support the dollar are techniques for fixing exchange rates; the recent moves to make the U.S. deficit and inflation comparable to those of other countries are techniques for coordinating budget policies. These policy actions should thus help to stabilize the dollar, but they provide only the first step toward stabilizing the international monetary system in the long run. 


\section{After the Fall}

\section{A Recession: Possible But Not Likely}

At present, it still appears that the anti-inflation program, despite some weaknesses, will help to reduce inflation. In addition, it appears that it will not cause a recession, because it is lowering people's expectations of inflation. When people expect the rate of inflation to be lower, interest rates are lower than they otherwise would be because the inflation premium shrinks. Contracts negotiated on the basis of expected inflation, such as labor contracts, also incorporate a smaller inflation premium. All this lowers costs for businesses and reduces inflation, but does not necessarily reduce output.

In contrast, when people do not expect inflation to come down, or when they are surprised by a new policy, then an effort to make policy tighter could affect economic growth. If tighter policies come as surprises, wages keep rising because workers' contracts were written in expectation of more inflation and cannot be changed. But businesses cannot raise prices as fast without losing customers, since other prices aren't rising as fast as expected. Workers thus become more and more expensive until some are actually paid more than the value of what they produce. Some workers, then, will be laid off. This is why government leaders were worried that actions to fight inflation would lead to higher unemployment and lower output.

The fall anti-inflation program will probably have mixed results, since it was neither totally anticipated nor totally unanticipated. The program itself came as a surprise, but once it was announced people seemed to expect a lower rate of inflation. Immediately following the announcement of the dollar defense program, for example, short-term interest rates rose and long-term interest rates fell. The rise in short-term rates was a predictable response to the Federal Reserve's attempt to slow the growth of money by making banks pay more for credit. It indicates little about people's expectations of inflation in the long run. The drop in long-term rates, however, signals that people expect either lower output or lower inflation in the next few years. If they were expecting lower output, the stock market logically should have declined, but in fact it shot up. This suggests that people are expect- ing lower inflation. The increase in the value of the dollar in foreign exchange further suggests that people are expecting an improvement in inflation, not a big drop in output.

All this is good news. As these expectations get incorporated in other interest rates and labor contracts, some inflationary pressures will be relieved. The more widely the success of the policy actions is anticipated, the more inflation can be reduced without cutting into output or employment.

Continued But More Moderate Growth in 1979 While the fall policy actions, particularly the dollar defense program, have improved the longer-term prospects for the economy, there is likely to be a small short-term pause in economic growth. A reasonable expectation for the year-over-year average real growth for 1979 is now in the range of 3 to 3.5 percent, mainly because short-term interest rates will weaken housing and business inventory accumulation.

Although the fall policy changes will make real growth less than it might have been, they were probably not a large enough surprise to the economy to precipitate a recession. Furthermore, one key indicator suggests that a recession is not likely: the opposing behavior of housing and business fixed investment. In the United States since World War II, neither business fixed investment nor housing by itself has been a good indicator of a recession, but together they have been reliable indicators. When housing has turned down and business fixed investment has remained strong, there has not been a recession. This has happened at least three times in the last thirty years and appears to be happening again.

Whatever happens to housing in 1979, real business fixed investment should continue to grow. It has not slumped or shown signs of a slump since the fall policy actions. New orders for nondefense capital goods grew at a rapid pace through the fall of 1978 . This indicates that businesses will continue to purchase equipment well into 1979, especially since large backlogs of orders have accumulated. New contracts for nonresidential building rose at a 20 to 30 percent rate through most of 1978, indicating that businesses will continue to expand their plants well into 1979 . Two surveys on total business investment in plant and equipment forecast continued growth in 1979, although at somewhat different rates. The Bureau of 
Economic Analysis survey, the more pessimistic view, predicts that business investment in 1979 will be 11 percent higher than in 1978 . The more optimistic survey, that of the Conference Board, predicts that it will be some 20 percent higher. It looks safe to say that business fixed investment will still grow in 1979 . As long as it keeps growing, the economy should avoid a recession even with a downturn in housing.

Why is business fixed investment looking so strong? Business expenditures on plant and equipment, far from being hurt by the anti-inflation program, are actually stimulated by it. The announcement of a definite program eliminates some of the uncertainty about future government policies and thereby reduces some of the risk of long-term investment in plant and equipment. If the program really does reduce inflationary expectations, businesses may also be paying a lower inflation premium in their long-term interest rates.

\section{The Success of the Anti-Inflation Program}

Although the anti-inflation program will have positive results, its success will be hard to see in the data for some time to come. The data cannot show that inflation would have been much, much worse if nothing had been done to stabilize the dollar. In addition, the published price indexes will reflect contracts signed well before the fall policy announcements, before most people were seriously expecting lower inflation. Customary pass-throughs of increased costs for higher minimum wages and social security taxes will also be reflected in the early 1979 price data. Consequently, prices are likely to continue to climb at about the 1978 rates or perhaps even higher. Inflation in 1979 should be significantly lower than it otherwise would have been-but this means that it will not be much better than the nearly 8 percent it averaged in 1978.

The fall policy changes, in brief, have improved the outlook for inflation and have not substantially altered the chances of a recession. While a recession is not the most likely event in 1979, neither is it an event with zero probability. Nevertheless, the Administration's decision to change policy still looks reasonable. When choosing between two policies with roughly the same chances of leading to a recession, the Administration chose the one that could do the most to fight inflation. Politically as well as economically, this seems to be the right decision because the econ- omy is still fundamentally strong and because people are more worried about inflation than any other economic problem. 